\title{
A Teoria da Ação à Luz da Experiência Esquizofrênica: um estudo de epistemologia insana
}

Gabriel Peters'

\section{Resumo}

As noções de "epistemologia insana" e"heurística da insanidade" nomeiam um artifício metodológico que se provou frutífero em uma variedade de domínios de pesquisa, qual seja, o mergulho no âmbito do "patológico" com vistas à iluminação de modalidades "normais" de ação e experiência. Lançando mão deste estratagema no plano das caracterizações sociológicas da conduta humana, o artigo mobiliza descrições fenomenológicas e existenciais de vivências esquizoides e esquizofrênicas, não apenas para compreendê-las à luz da teoria praxiológica da ação, mas também para aprofundar a teoria praxiológica da ação à luz do que aquelas descrições nos ensinam sobre a multiplicidade de modos de "ser-no-mundo" exibida pelo anthropos. O estudo defende que as transformações vivenciadas em processos esquizoides ou esquizofrênicos, a despeito de seus custos psíquicos, não devem ser concebidas como meros déficits funcionais, mas como atitudes existenciais complexas que "desafiam", em ato, certos postulados da teoria da ação em sua versão praxiológica: o ancoramento em crenças tácitas é substituído por uma compulsão hiper-reflexiva, a relação pragmática com objetos materiais dá lugar a uma perplexidade quase-filosófica em face de sua mera realidade, os acordos intersubjetivos que oferecem familiaridade e ordem à realidade social em dada cultura são percebidos na sua arbitrariedade ontológica radical e o estranhamento quanto ao próprio corpo deixa de ser um lúdico ceticismo cartesiano para tornar-se uma vivência existencial profunda.

Palavras-chave: Teoria da ação. Praxiologia. Esquizofrenia. Fenomenologia. Psicopatologia.

\section{Introdução}

De modo admitidamente provocativo, a noção de "epistemologia insana” refere-se a um procedimento analítico que rendeu frutos cognitivos nos

I Professor de Sociologia na Universidade Federal da Bahia (UFBA). Agradeço ao Professor Carlos Eduardo Sell pelo convite a participar do presente dossiê. Uma versão anterior desse trabalho foi apresentada no Grupo de Trabalho em Teoria Sociológica do XVII Congresso Brasileiro de Sociologia em julho de 2015, onde se beneficiou dos comentários de diversos participantes, aos quais também agradeço aqui. 
mais variados setores de pesquisa, desde a psicanálise de Freud até os estudos neurocientíficos contemporâneos. Tal procedimento, que também poderia ser alcunhado de "heurística da insanidade", toma o exame de formas "anômalas" ou "patológicas" de comportamento e experiência humana como caminho heurístico privilegiado para a compreensão de suas formas comparativamente "comuns" e "normais". Assim, por exemplo, o insight de que sintomas psicopatológicos poderiam ser decodificados como expressóes de conflitos inconscientes entre diferentes instâncias psíquicas forneceu a Freud (1976) um modelo geral da psique humana como uma entidade atravessada por relaçóes mais ou menos agonísticas entre as esferas do id ("isso"), ego ("eu”) e "superego" ("supereu”). De modo análogo, o progresso no entendimento dos processos neurológicos que subjazem à operação "normal" das faculdades subjetivas deve muito à pesquisa das dificuldades enfrentadas por indivíduos tragicamente vitimados por lesóes cerebrais, como um homem que se tornou incapaz de formar memórias novas após ter boa parte de seus lobos temporais mediais consumidos por um vírus (FOER, 2011, p. 77-80) ou outro que, após passar por uma separação cirúrgica dos hemisférios de seu cérebro, desenvolveu a chamada "síndrome da máo alienígena", em que uma de suas mãos ganha autonomia quanto à sua vontade consciente (por exemplo, desabotoando um botáo que a outra mão havia acabado de abotoar [LICKERMAN, 2012, p. 184]).

O presente ensaio, rebento de um trabalho mais amplo (PETERS, no prelo), pretende aplicar o estratagema metodológico da "epistemologia insana" ou "heurística da insanidade" às visóes sociológicas da açáo humana, em particular às perspectivas "praxiológicas" (RECKWITZ, 2002) que se tornaram sobremaneira influentes na teoria social contemporânea. A hipótese central é a de que "praxiologia" e "esquizofrenia" são verso e reverso, por assim dizer, de uma mesma moeda analítica. Assim, o trabalho mobiliza relatos fenomenológico-existenciais de vivências esquizoides e esquizofrênicas não apenas para entendê-las à luz da teoria praxiológica da ação, mas também para aprofundar a teoria praxiológica da ação à luz de tais relatos, isto é, do que eles nos ensinam sobre a multiplicidade de modos de "ser-no-mundo" (Heidegger) exibida pelo anthropos. O senso da autoevidência da realidade inscrito na "atitude natural", a orientaçáo fundamentalmente pragmática em relaçáo ao ambiente objetal e intersubjetivo, o caráter corporalmente engajado da ação cotidiana, o apoio prático em crenças e habilidades tácitas (não 
apenas no cumprimento de tarefas rotineiras, mas também como o pano de fundo indispensável de deliberaçóes reflexivas) - estes e outros traços de nosso ser-no-mundo, hegemonicamente incluídos em retratos da agência humana na teoria social contemporânea graças às perspectivas praxiológicas, estão precisamente entre as disposiçôes subjetivas radicalmente transformadas em diversos processos esquizoides ou esquizofrênicos. Calcado nos trabalhos de psiquiatras fenomenologicamente informados como Louis Sass e Thomas Fuchs, este artigo parte da hipótese de que tais transformaçóes, a despeito de seus custos psíquicos e sociais, não devem ser concebidas como meros déficits agenciais e experienciais, mas como atitudes existenciais complexas que requerem uma descrição tão minuciosa quanto possível - atitudes nas quais, por exemplo, o ancoramento em crenças tácitas é substituído por uma compulsão hiper-reflexiva, a relação pragmática com objetos materiais dá lugar a uma perplexidade quase-filosófica em face de sua mera realidade, os acordos intersubjetivos que oferecem familiaridade e ordem à realidade social em dada cultura são percebidos na sua arbitrariedade ontológica radical e o estranhamento quanto ao próprio corpo deixa de ser um lúdico ceticismo cartesiano para tornar-se uma vivência existencial profunda.

\section{Para uma heurística da insanidade: teoria social e "sensibilidade psicopatológica"}

A relação de fertilização recíproca entre reflexão teórica e pesquisa empírica que é comumente apregoada em diversas paragens sociológicas (por exemplo, BOURDIEU e WACQUANT, 1992, p. 162) pode ser lida, interalia, como uma tentativa de explorar a tensão dialética entre generalidade e particularidade no discurso sociológico. Por um lado, a explicaçáo de fenômenos empíricos em contextos sócio-históricos particulares não pode escapar ao recurso (explícito ou implícito) a certos conceitos e proposiçóes gerais, nos quais estão imiscuídos inevitáveis pressupostos teóricos acerca da condição humana em sociedade. Ao mesmo tempo, qualquer discurso sobre o animal social humano que almeje a responsáveis pretensóes de universalidade é obrigado a temperar tais pretensóes pelo recurso a uma sensibilidade atenta à particularidade, isto é, à multiplicidade de formas de ação e experiência exibidas por esse notável bípede implume. Como acontece em tantos outros domínios da ciência social, o caminho heuristicamente mais profícuo para lidar com a 
relação tensa entre a generalidade do humano e a particularidade dos humanos parece ser a tentativa de pensá-las simultaneamente, em vez de absolutizar um dos polos à custa do outro.

Ao afirmar que as propensóes generalizantes do discurso teórico sobre a agência humana e a vida social têm de ser disciplinadas pela atençáo à exuberante diversidade de modos humanos de ser-no-mundo, podemos sublinhar a relevância das análises de contextos sociais particulares legadas pela história e pela antropologia para o cumprimento de tal tarefa. Há, no entanto, outro domínio fenomênico a partir do qual caracterizaçóes teóricas da conduta socialmente situada podem ser qualificadas ou relativizadas na sua aplicabilidade, qual seja, o dos estados de espírito, formas de comportamento ou modalidades de experiência cuja singularidade termina por ser socialmente classificada como psicopatológica ${ }^{2}$. Nesse sentido, uma "sensibilidade psicopatológica” na

2 Cabe aqui um breve excurso conceitual sobre a "doença" como experiência e representação. A sociologia permanece eivada de controvérsias no que toca à conceituação das doenças mentais, controvérsias que se estendem à possibilidade mesma de um uso intelectual elou moralmente legítimo da expressão de origem médica - com ou sem aspas. A maior parte dos cientistas sociais tende a esposar simpatia pela tese social-construtivista de que os rótulos psiquiátricos são, antes de tudo, ferramentas socioculturais através das quais as sociedades em geral, e certas instituições de "saber-poder" (Foucault) em particular, lidam com modalidades socialmente desaprovadas de comportamento anômalo ou desviante. Enquanto um crítico feroz da psiquiatria como Thomas Szasz (196I) busca combinar essa visão de matiz sociológico a um argumento médico segundo o qual a noção de "doença mental" não possui qualquer sentido cientificamente defensável, outras abordagens sociológicas podem acalentar simplesmente uma espécie de agnosticismo quanto ao status ontológico último das categorias psiquiátricas, cingindo-se à análise de como elas são socialmente mobilizadas em ações e interações humanas (por exemplo, BERGER; LUCKMANN, 1985, p. 153-154; BERGER, 2003, p. 36). Seja como for, a influência da teoria do desvio social e da rotulação (labeling) na sociologia (BECKER, 1963; SCHEFF, 1966) e do relativismo psiquiátrico encorajado pela escola de "Cultura e Personalidade" na antropologia (BENEDICT, 1939) responde pelo fato de que a teorização sociológica acerca das doenças mentais constitui mais uma análise do discurso psiquiátrico e de seus efeitos sociais e institucionais do que propriamente uma discussão das condições em que emergem, se desenvolvem e se transformam as próprias "psicopatologias" (LAHIRE, 2008, p. 373). Dentre os especialistas científico-sociais em doenças mentais que aceitam a validade das categorizações psiquiátricas, a maior parte trabalha não na esfera da reflexão teórica, mas com pesquisas empíricas que versam sobre a descrição e a explicação das taxas diferenciais de incidência de psicopatologias exibidas por distintos estratos sociais de classe, gênero, etnicidade, idade e assim por diante (ANESHENSEL $e$ PHELAN, 1999). O presente estudo busca trilhar uma via média para além das unilateralidades de ambos os polos do debate sobre a validade das categorias psiquiátricas. De um lado, ele sustenta que as formas de experiência e comportamento socialmente classificadas como sintomas de "doenças mentais" são reais e requerem descrição e explicação, independentemente de como sejam rotuladas. Por outro lado, na medida em que a autointerpretação do individuo afligido, bem como as respostas sociais à sua condição, condicionam suas manifestações sintomáticas e o curso de suas experiências, o efeito performativo de saberes (etno)psiquiátricos não pode ser ignorado nem mesmo em uma investigação que se pretenda centrada apenas sobre as próprias psicopatologias. Grossíssimo modo, a atribuição de psicopatologia envolve não somente o diagnóstico de 
teoria social pode ser entendida como uma compreensão da agência e da vivência humana em sociedade informada pelo que a psicopatologia descritiva nos mostra a respeito da multiplicidade de formas - mais ou menos inteligíveis, mais ou menos bem-sucedidas, mais ou menos (in)felizes- de estar no mundo.

A aproximação entre uma sensibilidade psicopatológica, de um lado, e as sensibilidades histórica e antropológica, de outro, serve ao propósito de mostrar o quanto a compreensão da doença mental qua experiência ${ }^{3}$ permite alargar nosso conhecimentoda pluralidade de modalidades de ação e vivência humana. Ao mesmo tempo, tal qual a história e a antropologia, esse alargamento continua revelando tais modalidades como modalidades de ação e vivência humana. Dessa forma, o registro da diversidade na unidade contribui para a sua contraparte: o revelar da unidade na diversidade (GUSMÃO, 2012, p. 105). Os retratos historiográficos ou etnográficos dos modos pelos quais membros de diferentes coletividades distribuídas no tempo e no espaço operam no mundo, bem como o pensam e o sentem, não acarretam apenas um testemunho da pluralidade comportamental e experiencial de nossa espécie. Eles também dão testemunho de que instituiçôes, práticas e representações prima vista bizarras e ininteligíveis à luz de nossos referenciais socioculturais podem ser imbuídas de compreensibilidade, ou até mesmo de identificação

um significativo "desvio estatístico" em relação ao que se concebe como "norma" do funcionamento mental, mas também a asseveração de que tal desvio é, de algum modo, prejudicial, de um ponto de vista cognitivo, emocional e prático, ao individuo que o manifesta elou àqueles do contexto social em que ele está imerso. Ter em mente a vergonhosa criminalização da homossexualidade na Inglaterra vitoriana ou a internação de dissidentes políticos em hospícios na antiga União Soviética deve ser suficiente para que se exclame: "prejudicial a quem?". A pergunta é importante, assim como o registro histórico e a denúncia moral dos horrores cometidos em nome da instituição psiquiátrica. Mas também é fundamental não romantizar a condição do louco a ponto de se pensar absurdamente que a psiquiatria constitui simplesmente uma oferta sem demanda - a demanda existiu e existe sob a forma dos extraordinários sofrimentos, privações e provações vivenciados pelos individuos afligidos por certos transtornos graves (sublinhe-se vigorosamente o substantivo e o adjetivo). A mesma sensibilidade compassiva que estimula a denúncia moral dos tratamentos desumanos ou das patologizações injustificadas deve também justificar, portanto, a impossibilidade de se permanecer indiferente ao calvário de certas condições psíquicas e a urgência correlata de esforços terapêuticos de alguma natureza (MERQUIOR, 1985, p. 30; GRAHAM, 2010, p. 20).

3 Como tal, a descrição fenomenológica das vivências do doente mental é compativel com as posições explanatórias mais diversas acerca das suas causas. Com efeito, mesmo uma abordagem neurobiológica que tome o conjunto das experiências mentais como "espuma fenomenológica" (ARCHER, 2003, p. 45), isto é, meros epifenômenos de processos físicos ocorrendo no cérebro, ainda sim tem de identificar a natureza do seuexplanandum, ou seja, das vivências subjetivas que pretende explicar (NAGEL, 20I2, p. I67). 
empática, quando situadas em um relato detalhado das circunstâncias nas quais emergem e funcionam. $\mathrm{O}$ mero fato da comensurabilidade relativa entre visóes de mundo, de que uma boa dose de compreensão intercultural ou "fusão de horizontes" (GADAMER, 1997, p. 457; GEERTZ, 2000, cap.3) histórico-hermenêuticos distintos é possível, indica a possibilidade de encontrarmos uma unidade subjacente à diversidade ou mesmo "pré-condições imutáveis da mutabilidade" dos seres humanos (HONNETH; JOAS, 1988, p. 7). Com base nesse pressuposto, este trabalho busca conectar-se a uma longa tradição interdisciplinar que procura no enigma da esquizofrenia um caminho para a compreensão de alguns dos principais desafios e dilemas da condição humana como tal (JENKINS, 2004).

\section{A “galáxia praxiológica”4 na teoria social}

Tornou-se lugar comum, na teoria social contemporânea, reconhecer que o mundo societário não deve ser tido simplesmente como um dado que se impóe aos atores a partir do exterior. Ele precisa, em vez disso, ser tomado na sua radical historicidade, isto é, como um resultado contínuo e contingente de condutas motivadas e habilidosas sendo levadas a cabo em uma multiplicidade de cenários. A versão mais influente de tal caracterização radicalmente historicizada do mundo social e de suas estruturas aparece nas correntes praxiológicas capitaneadas por autores como Anthony Giddens e Pierre Bourdieu, correntes cujas fundaçóes remontam, no mínimo, à ontologia da práxis delineada pelo Marx das Teses sobre Feuerbach (2000). O acento sobre a contingência histórica da ordem social e seus suportes demanda de tais abordagens uma explicaçáo de como os agentes situados mantêm em existência, através de suas práticas subjetivamente propelidas, as propriedades estruturais do mundo societário. A propulsão subjetiva das práticas humanas possui tanto um aspecto motivacional ou volitivo, referente às intençóes ou finalidades mais

4 A expressão parafraseia o termo "galáxia construtivista", cunhado por Corcuff (200 I) para designar as perspectivas teórico-metodológicas que não tomam o social simplesmente como um dado explanatório de outros fenômenos (e.g., condutas individuais), mas como uma realidade histórica contingente que requer ela própria explicação em termos de seus mecanismos de produção, reprodução e transformação. As visões praxiológicas da agência humana e do mundo social abraçam tal postulado construtivista, mas se distinguem de outras versões da ontologia social construtivista em função de sua particular especificação daqueles mecanismos (SCHATZKI, 1996; RECKWITZ, 2002; PETERS, 201 Ia; 20 I lb; 20I3a; 20I3b). Nesse sentido, se, por um lado, toda perspectiva praxiológica é construtivista na acepção corcuffiana do termo, nem toda abordagem construtivista é necessariamente praxiológica. 
ou menos conscientes que impulsionam os atores a intervir sobre seus cenários de experiência, quanto uma dimensão recursiva ou procedimental, relativa às habilidades cognitivas, práticas e expressivas que capacitam os agentes a realizar aquelas intervençóes com maior ou menor eficácia.

Os heróis da guinada praxiológica na teoria social oferecem descrições sofisticadas dos motores subjetivos envolvidos na produção da agência que, por sua vez, produz, reproduz ou transforma historicamente o mundo societário. Ao mesmo tempo, como representantes do "novo movimento teórico" (ALEXANDER, 1987) que observaram a crítica ao objetivismo parsoniano chegar a extremos de subjetivismo, Giddens e Bourdieu defenderam que a produção do social pelos agentes é apenas a face de uma mesma moeda que inclui, do outro lado, a produçáo dos agentes pelo social. Em outros termos, os dois autores sublinharam que as próprias motivaçôes e capacidades que os atores investem cronicamente nas condutas que produzem e reproduzem o mundo social carregam necessariamente as marcas de sua socialização prévia nas estruturas desse mesmo mundo (BOURDIEU, 1983, p. 47; 1990a, p. 149-152; GIDDENS, 1993, p. 128-129; 2003, p. 29-33; PETERS, 2015).

Através de tal manobra teórica, os artífices da síntese praxiológica buscavam incorporar as virtudes heurísticas das microssociologias interpretativas que haviam ganhado destaque como reaçóes críticas ao pendor objetivista do estrutural-funcionalismo parsoniano, mas sem deslizar, no entanto, para um polo oposto de subjetivismo desavergonhado (PARKER, 2000). Dentre tais microssociologias interpretativas que coloriram a cena intelectual posterior à derrocada da hegemonia de Parsons na teoria sociológica, Giddens e Bourdieu foram mais significativamente influenciados pela redescoberta da fenomenologia social de Alfred Schutz (a bem da verdade, um contemporâneo do "incurável teórico" da sociologia estadunidense), pela etnometodologia de Harold Garfinkel e pela pragmática da linguagem do segundo Wittgenstein. Nessa constelação de influências intelectuais, encontraremos uma série de postulados que permanecem até hoje hegemônicos na teoria social, a ponto de nos oferecerem a base reversa, por assim dizer, para um retrato das formas anômalas de ação e experiência que descreveremos mais adiante. Quais postulados? Grosso modo, um conjunto de motivos anticartesianos extraídos não apenas dos três autores citados acima, mas também de figuras como Heidegger, Merleau-Ponty, Dewey e vários outros. Alguns elementos desse conjunto de teses: 
a) $\mathbf{O}$ agente no mundo: As operaçōes da subjetividade só podem ser analisadas em seu entrelaçamento originário e inescapável com o mundo ${ }^{5}$, considerado tanto em sua dimensão material quanto como teia de significados e símbolos intersubjetivamente partilhados que moldam a própria psique individual.

b) A cultura como mediaçáo da práxis e a práxis como mediação da cultura: Há uma espécie de "retroalimentação" ou interdeterminação dialética (BOURDIEU, 1988a, p. 52) entre os instrumentos simbólicos pelos quais os agentes organizam, tácita e espontaneamente, a experiência de seus contextos mundanos, de um lado, e a própria organização exterior de práticas e relaçóes nos quais os atores estáo "lançados" (Heidegger), de outro.

c) A naturalidade e a autoevidência do mundo da vida: A relação de "cumplicidade ontológica" entre as estruturas sociais objetivas em que os agentes são socializados e circulam, de um lado, e as estruturas mentais de percepção e orientação prática que movem suas açóes, de outro, faz com que suas experiências do mundo social sejam banhadas em uma aura de naturalidade e autoevidência imediatas.

d) $\mathbf{O}$ conhecimento prático: A orientação subjetiva do agente em face de seu ambiente mundano, humano assim como objetal, é fundamentalmente pragmática, capacitada por "estoques de conhecimento" (SCHUTZ, 1979, p. 74) cujo cultivo e operação derivam de sua atuaçáo interessada na persecução de objetivos no mundo social. Tanto as intençóes quanto as habilidades subjetivamente mobilizadas em tais condutas situadas não se situam completamente, ou mesmo predominantemente, no domínio de uma consciência explícita e discursivamente articulada, mas em um âmbito tácito e infradiscursivo (GIDDENS, 2003, p. 440).

e) Carne pensante: $\mathrm{O}$ corpo dos agentes não é apenas, ou fundamentalmente, um objeto de representação ou o veículo passivo dos processos mentais, mas o locus primordial das intencionalidades e competências práticas que

5 "Ao dirigir-se para...e apreender, a presença [Dasein] não sai de uma esfera interna em que antes estava encapsulada. Em seu modo de ser originário, a presença já está sempre 'fora', junto a um ente que the vem ao encontro no mundo já descoberto" (HEIDEGGER, 2006, p. 109). "[...] o que se quer dizer quando se diz que não há mundo sem um ser no mundo? Não que o mundo é constituido pela consciência, mas, ao contrário, que a consciência sempre se encontra já operando no mundo" (MERLEAU-PONTY, 2002, p. 579). 
motivam seu engajamento cognitivo, prático e afetivo com o mundo social - em outras palavras, os agentes não apenas possuem corpos como são corpos expostos às injunçóes e condicionamentos da realidade (PLESSNER, 1970; BOURDIEU, 1990b, p. 73; CROSSLEY, 2001b).

f) $\mathbf{O}$ objeto da teoria social: As relaçôes sociais produzidas e reproduzidas através de práticas motivadas e hábeis não se reduzem ao domínio intersubjetivo, mas envolvem complexas associaçóes entre humanos e não humanos, incluindo-se aí os artefatos técnicos pelos quais os primeiros intervêm sobre seus ambientes materiais e são, ao mesmo tempo, transformados por eles (RECKWITZ, 2002).

g) A precedência da intersubjetividade simbolicamente mediada sobre a subjetividade individual: Como indicado em (b), a operaçáo mesma da subjetividade individual é habilitada por meios simbólicos intersubjetivamente partilhados, nela inculcados pela experiência socializadora em um dado contexto sociocultural. Do ponto de vista metodológico, isto implica que o caminho heurístico mais adequado à teoria social não é o que principia pelas intençôes e competências do ator individual com vistas à compreensão da intersubjetividade simbolicamente mediada, mas aquele que perfaz o sentido inverso (GIDDENS, 1998, cap.8).

h) A sensação difusa da sociedade: As dimensóes da agência humana e da vida social comumente diferenciadas na teoria sociológica para fins analíticos encontram-se entrelaçadas na existência concreta do mundo societário: movimentos do corpo e orientaçóes da mente, interesses pragmáticos e operaçóes cognitivas, relaçóes intermentais e intercorpóreas etc. A experiência individual do universo social, em consequência, não se reduz a uma representação cognitiva, mas constitui vivência global e difusa de uma realidade que, como o tempo segundo a famosa frase de Santo Agostinho ${ }^{6}$, é tão óbvia na sua facticidade quanto elusiva na sua descritibilidade.

$\mathrm{Na}$ medida em que não estamos lidando com uma perspectiva sistematicamente elaborada até o mínimo detalhe, mas com a realidade mais vaga de uma "atmosfera" intelectual que emergiu na teoria social a partir de uma

6 "O que é...o tempo? Se ninguém me perguntar, eu sei; se o quiser explicar a quem me fizer a pergunta, já não sei" (AGOSTINHO, 2000, p. 322). 
multiplicidade de contribuições autorais, a discussão que se segue estará mais interessada em sublinhar as convergências socioteóricas entre os autores mencionados do que em explorar as diferenças entre eles. Ao mesmo tempo, a metáfora atmosférica pretende evidenciar o quão misturadas estáo essas teses em um retrato global da ação humana ordinária no mundo social, a ponto de poderem ser tidas como dimensóes apenas analiticamente distinguíveis de uma mesma pintura fenomênica. $O$ que esta pintura tem a ver com a esquizofrenia?

\section{Sintomas positivos e negativos na esquizofrenia}

A psiquiatria das últimas décadas tem sido palco de uma significativa busca de consenso na taxonomia dos distúrbios mentais, em uma tendência cuja principal corporificação encontra-se nas sucessivas ediçóes do DiagnosticandStatistical Manual of Mental Disorders (DSM), periodicamente composto e recomposto pela Associação Psiquiátrica Americana (2000). Tal esforço de listagem precisa de sintomas psicopatológicos não poderia deixar de se debruçar também sobre aquele que é, provavelmente, o mais polissêmico dos termos reinantes na nosologia psiquiátrica: esquizofrenia. $\mathrm{O}$ fato de estarmos diante de uma categoria "guarda-chuva" que abarca, para fins de conveniência teórica e prática, uma multiplicidade de configuraçóes psicopatológicas sob uma única rubrica foi reconhecido pelo próprio criador do termo: EugenBleuler. Ao propor essa categoria, em 1911, para substituir o conceito de dementiapraecox previamente avançado por Emil Kraepelin, Bleuler já havia feito questáo de vincar essa desconcertante heterogeneidade ao referir-se ao "grupo das esquizofrenias" (1969). No mesmo passo, ao justapor os radicais gregos que indicam respectivamente "cisão" e "mente", o autor buscou encapsular os vários sentidos em que a psicopatologia em foco envolvia fissuras na relação do indivíduo consigo mesmo (e.g., nos processos de associação de ideias ou de conexóes entre pensamentos e afetos) e com o mundo circundante.

A caracterização da condição esquizofrênica perfilada nas ediçóes mais recentes do DSM distingue entre sintomas positivos e negativos (JENKINS; BARRET, 2004). Uma vez que o conjunto da sintomatologia esquizofrênica é visto como fonte de sofrimentos psíquicos e desajustes sociais para os indivíduos afligidos, os epítetos não designam atribuiçóes de valor, mas esquadrinham diferentes sintomas em termos de seu papel prima vista "produtivo" 
ou "restritivo" no tocante às açóes, pensamentos e sentimentos do indivíduo. Nesse sentido, os sintomas positivos seriam vistos como práticas ou vivências efetivamente desencadeadas pela doença, tais como raciocínios e discursos significativamente desorganizados, interpretaçóes ilusórias da experiência e percepções alucinatórias:

Apenas algum tempo após eu ser confinado à minha cama, comecei a ouvir vozes, primeiramente apenas próximas ao meu ouvido, depois em minha cabeça, ou como se alguém estivesse sussurrando em meu ouvido - ou em várias partes do quarto. [...] Essas vozes me ordenavam a fazer - e me faziam acreditar em - um número de coisas falsas e terríveis. Estou pensando em minha mãe, e, de repente, meus pensamentos são sugados da minha mente por um aspirador frenológico, e já não há nada em minha mente. (apud FRITH; JOHNSTONE, 2003, p. 6; 36).

Os sintomas negativos, por sua parte, constituiriam os aspectos da esquizofrenia primordialmente compreensíveis como prejuízos ou reduçóes no desempenho das modalidades tidas como normais de pensamento, conduta e comunicação. Essa dimensão da psicopatologia manifestar-se-ia, sobretudo, como um déficit nas propensóes conativas que induzem os indivíduos "sãos" a um engajamento intenso e emocionalmente responsivo em atividades e interaçóes socialmente valorizadas. Tal déficit seria tornado evidente, por exemplo, na parca expressão de afetos, no empobrecimento da articulação verbal, no desinteresse pelas pessoas, objetos e eventos presentes no ambiente imediato e assim por diante:

Estou mais e mais perdendo contato com o meu ambiente e comigo mesmo. [...] Estou perdendo, o tempo todo, meu contato emocional com tudo, inclusive eu mesmo.[...] Meu destino, quando eu reflito a respeito, é o mais horrível que se pode conceber. Não posso imaginar nada mais assustador do que um ser humano bem cultivado viver sua própria deterioração gradual com plena consciência. Mas é isto que está acontecendo comigo. (apud FRITH; JOHNSTONE, 2003, p. 2).

Como nota Louis Sass (2004, p. 304), a incidência estatística dos sintomas negativos é maior do que aquela dos sintomas positivos na populaçáo de esquizofrênicos. Além disso, os últimos, quando aparecem, tendem a fazê-lo na fase mais aguda da doença, enquanto os primeiros são salientes nas suas etapas iniciais e/ou residuais. Pois bem: o modo pelo qual Bleuler se aproximou dos sintomas negativos da esquizofrenia reflete-se na sua noçáo 
do "autismo" do esquizofrênico. Subjacente à análise do autor parece estar uma noção da personalidade como uma estrutura de encadeamentos entre pensamentos, afetos e condutas práticas de intervençáo no mundo externo. A trajetória de socialização no seio de uma formação societária responderia pela relativa partilha intersubjetiva de tais encadeamentos intrassubjetivos entre ideias, entre cogniçóes e emoçóes, entre estados subjetivos e manifestações comportamentais etc. Nesse sentido, o que Bleuler viu como sintoma primeiro das condiçóes esquizofrênicas foi precisamente um enfraquecimento ou ruptura em tais modos frequentes e partilhados de associação subjetiva entre pensamentos e sentimentos. Tal fenômeno tendia a ser seguido, a seu ver, por reagrupamentos associativos que discrepavam dos padróes normais de operação da cognição e dos afetos. Na literatura psiquiátrica, tais manifestaçóes de ruptura nas articulaçóes tidas como normais entre pensamento e emoção foram denominadas de "ataxia intrapsíquica" pelo psiquiatra austríaco Erwin Stransky (apudSASS, 1992, p. 416) ${ }^{7}$.

Embora Bleuler jamais tenha se convertido plenamente à causa psicanalítica, não há dúvida de que o modelo bleuleriano da esquizofrenia como afrouxamento das conexóes ideativas reguladas pelo "princípio de realidade", afrouxamento seguido de um processo desorganizado, instável e fluido de produçáo de novas e estranhas associaçóes entre pensamentos e afetos, trai uma influência do retrato freudiano do mundo onírico (MORGAN, 2010, p. 179). Uma vez que as representaçóes mentais e associaçóes ideativas que circulam no espaço interno da mente são "afetivamente carregadas" (BLEULER, 1950, p. 353), o afrouxamento ou desatar dos nós entre cogniçóes implicaria necessariamente um afrouxamento ou desatar de complexos emocionais outrora estáveis, resultando em uma marcada instabilidade emocional em que o indivíduo oscila entre estados ostensivamente distintos de humor.

Finalmente, sob a enorme pressáo existencial colocada pela vivência da própria desorganização cognitiva e afetiva, magnificada pelos desafios práticos

7 Um dos exemplos mais frequentes desse fenômeno consiste na reportada tendência do esquizofrênico ao "humor inapropriado" (Bleuler) e à "hilaridade sem sentido" (Kraepelin), isto é, a rir em situações socialmente inadequadas e sem motivos imediatamente inteligiveis a um observador externo. Naturalmente, uma vez quese acessa a perspectiva particular a partir da qual o indivíduo enxerga tal ou qual situação, bem como as associações ideativas pouco usuais engendradas por tal perspectiva, os risos socialmente inapropriados dos esquizofrênicos podem revelar-se perfeitamente compreensiveis (SASS, 1992, p. 143). 
e emocionais de uma existência partilhada com outros, o indivíduo esquizofrênico procura isolar-se em um mundo interno, apartando-se de cenários de interaçáo social e de busca de objetivos coletivamente valorizados. Bleuler escolheu chamar de "autismo" (1950, p. 373) a esse estado de fuga para um universo subjetivo, acompanhada pela desistência da participação nas atividades do mundo da vida. Embora sua teoria da progressáo dos estados esquizofrênicos explique essa condiçáo autista como resposta angustiada às experiências primárias de desestruturaçáo dos encadeamentos cognitivos e afetivos constitutivos da personalidade, uma pletora de investigadores da condição esquizofrênica veio a conferir primazia aos elementos vislumbrados na noção de autismo empregada pelo autor. Tais elementos são todos retraçáveis a uma perturbação ou fissura nos sensos básicos de conexão experiencial característicos de uma condição de "contato vital com o mundo" (MINKOWSKI, 2002, p. 106) ou "segurança ontológica" (LAING, 1990, p. 39): conexão entre o indivíduo e ele próprio, entre o indivíduo e o mundo material, entre o indivíduo e o mundo das outras mentes.

As articulaçóes de sentido que podemos propor entre conceitos como "autismo" (Bleuler), "perda de contato vital com a realidade" (Minkowski) e "insegurança ontológica” (Laing) devem ser lidas, é claro, menos como simples sinonímias ou cadeias diretas de influência intelectual do que como "semelhanças de família" (Wittgenstein) entre retratos relativamente autônomos da experiência esquizofrênica. Como já indicado pelo seu modo de expressão, a descrição minkowskiana da "perteducontact vital aveclaréalitê" (MINKOWSKI, 2002, p. 106) como núcleo da esquizofrenia bebe da filosofia do "tempo vivido" de Henri Bergson, em particular de seu retrato da experiência intuitiva do tempo como imersão em um fluxo ininterrupto que ele chamou de "durée", contrastando-a às operaçóes de abstração e "espacialização" pelas quais buscamos decompor tal fluxo pela identificação de instantes temporais descontínuos. No presente contexto, estamos menos interessados em adentrar os detalhes da filosofia do tempo que Bergson legou a Minkowski do que em registrar o influxo dessaLebensphilosophie na noção de "contato vital com o mundo", aventada pelo último para designar aquela imersão pré-reflexiva e pré-predicativa em cenários mundanos que também seria descrita por Heidegger e Merleau-Ponty. É a própria natureza difusa desse contato existencial bem assentado consigo mesmo, com os objetos materiais e com as outras pessoas, 
uma experiência em que tudo isso é espontaneamente vivido como realidade indubitável, que explica o caráter algo vago de conceitos como "contato vital" (Minkowski), "presença” (Heidegger/Merleau-Ponty/Bourdieu), "autoevidência natural" ou "senso comum" (Blankenburg).

Afrouxar nossos parâmetros de exatidão conceitual pelo bem do máximo realismo de nossas caracterizaçóes psicológicas não significa, entretanto, que náo possamos jogar luz sobre diversos elementos heuristicamente discerníveis nessa experiência global de si, do mundo e dos outros como realidades evidentemente bem-fundadas. Com efeito, a formulação já elenca alguns dos traços que Laing julgou serem componentes indispensáveis de uma sensação existencial difusa de "segurança ontológica" (1990, p. 39). Em primeiro lugar, um senso integral de identidade pessoal que envolve uma noção firme da própria existência como distinta daquela de outras pessoas, uma experiência de continuidade do próprio self ao longo do tempo e a vivência tácita, pois tida como autoevidente, de quaisquer pensamentos, imagens e sentimentos que emergem no campo interno da subjetividade como "meus" (JASPERS, 1979b, p. 701). Uma experiência global de segurança ontológica náo envolve apenas a relação de si a si, mas também a vivência de um relacionamento estável entre si mesmo e o mundo das coisas, no qual a substancialidade, a cognoscibilidade e a existência continuada do último não são postas em questáo, mas simplesmente pressupostas como o pano de fundo evidente da lida cotidiana. $\mathrm{O}$ atributo da substancialidade supóe que as entidades que experimentamos como exteriores existem efetivamente na realidade "lá fora", independentemente de nossa subjetividade e imbuídas de propriedades idênticas, similares ou, pelo menos, não radicalmente distintas daquelas que percebemos nelas. A relação de "presença” ao mundo que marca a experiência ontologicamente segura depende de uma "confiança” (GIDDENS, 2003, p. 444) ou "fe"" (MERLEAU-PONTY, 1971, p. 15) em nossas capacidades subjetivas de registrar seus padróes de operação tais como sáo em si mesmos. Essa aposta cognoscitiva, por sua vez, ata-se ao que Laing retrata como uma pressuposiçáo quanto à "confiabilidade [reliability] dos processos naturais" (1990, p. 39) graças à qual nossa trajetória existencial pode se valer de um grau relativo de previsibilidade - sem o que nossa ansiedade poderia sair de controle. E o que vale para o mundo das coisas também vale, mutatis mutandis, para o universo das outras pessoas: supomos sua "substancialidade", isto é, sua existência "fora" e independente de nós, apostamos na sua relativa cognoscibilidade para todos 
os propósitos práticos e, por fim, mobilizamos expectativas quanto aos comportamentos prováveis e improváveis que delas podemos esperar, o que serve para mitigar um sem-número de incertezas angustiantes quanto ao que farão.

\section{$O$ reverso esquizo da praxiologia}

Podemos, agora, articular os dois eixos deste trabalho. Primeiramente, ancoramo-nos em Heidegger, Wittgenstein, Merleau-Ponty, Bourdieu e Giddens para delinear (muito brevemente, devido às limitaçóes de espaço) os principais postulados da caracterização praxiológica da ação humana no mundo social. Com efeito, uma das maneiras mais pedagógicas de compreender a integraçáo destes postulados em uma visáo geral de condutas e experiências humanas é ver tal integração como uma superação crítica de dualismos analíticos como mente/mundo, sujeito/objeto, mente/corpo, indivíduo/sociedade e assim por diante (PARKER, 2000, p. 42). É claro que, grosso modo, as principais estrelas autorais na galáxia praxiológica reconhecem de bom grado que circunstâncias sócio-históricas concretas de ação, embora tenham de se encaixar em alguma medida naquele retrato socioteórico, podem desviar dos seus contornos em maior ou menor medida. A precedência heurística do modelo praxiológico da açáo no mundo social não implica sua absoluta e inflexível aplicabilidade a todo e qualquer cenário sócio-histórico, mas o fato de que mesmo situaçóes que se afastam do modelo podem ser mais facilmente compreendidas como "desvios" maiores ou menores em relação aos seus postulados (COHEN, 1999, p. 401-402).

Se a tônica da visão praxiológica do universo social e suas entidades constituintes é a superação de dualismos, aquilo que chamo de "reverso esquizo da praxiologia" consiste precisamente nos cenários de ação e experiência em que irrompem graus significativos de fissuras ou cisöes normalmente inexistentes entre as diferentes dimensôes da práxis social: a subjetividade e o mundo, a mente e o corpo, o material e o simbólico etc. O conceito de "esquizoidia" ou "experiência esquizo" advogado no presente trabalho pode ser, nesse sentido, ampliado para além das condiçôes mais graves de doença esquizofrênica, abarcando um continuum de níveis de ruptura (sublinhe-se o "esquizo") de alguma(s) das "cumplicidades ontológicas" que a prática normal mantém fluentemente. A premissa que subjaz à análise da esquizoidia e da esquizofrenia desenhada no presente texto é a de que os enigmáticos "desvios" e 
"perturbações" comportamentais e experienciais que caracterizam a condição esquizo podem ser mais bem compreendidos se tomados ideal-tipicamente como "avessos" da conduta humana qua retratada na praxiologia. Como foi visto, a concepção praxiológica da condição humana constituiu-se explicitamente contra determinadas atitudes típicas da filosofia moderna, tais como o retrato dualista da relação mente/corpo ou mente/mundo, a noção de cogniçáo desinteressada própria à epistemologia fundacionista ou a psicologia atomista da percepção como reuniáo a posteriori de fragmentos perceptuais. Por conseguinte, como avessos da praxiologia, certos modos esquizoides ou esquizofrênicos de ser-no-mundo terminam por apresentar-se como singulares "concretizaçóes" existencialmente vividas daquelas atitudes filosóficas contra as quais a praxiologia se constituiu. Exemplos?

O "contato ingênuo com o mundo" (Merleau-Ponty) que caracteriza o realismo cotidiano pode ser substituído, na prática, por uma radical (e frequentemente ansiosa e paralisante) suspeita epistemológica em relaçáa às próprias impressóes subjetivas da existência. A experiência de ser corpo, isto é, de experimentar a própria fisicalidade como um instrumento prático de intervenção motivada e competente sobre os cenários mundanos pode dar lugar a uma experiência "cartesiana" de estranhamento profundo quanto à própria materialidade, à vivência de ser pura consciência alocada em um corpo estranho, um espírito tentando animar uma carcaça ou um "cadáver com insônia" (SASS, 1992, p. 419). Os interesses conativos que propelem as atividades cognitivas ordinárias de seleção e classificação podem ser dissolvidos por uma apatia prático-afetiva que não paralisa as faculdades mentais, mas mostra como, de fato, funciona uma cognição volitivamente desinteressada pelo mundo: categorizaçôes "tipificantes" (Schutz) são substituídas por uma massa de impressóes de objetos singulares, enquanto as Gestalten, isto é, as totalidades estruturadas e significativas da percepção corriqueira, podem ser fragmentadas em átomos perceptuais não conectados entre si.

Compreender certas condiçóes esquizoides ou esquizofrênicas segundo essa grade interpretativa implica, de fato, reconhecer que, pelo menos em uma variedade de casos, açóes e comportamentos apressadamente vistos como meras excreçôes mentais de um cérebro doente revelam-se muito mais complexos e interessantes do ponto de vista psicológico. Ao mesmo tempo, não descurar de uma investigação dos custos psíquicos extraordinários que, segundo os 
depoimentos dos próprios indivíduos, acompanham a condição também nos impede de deslizar para qualquer celebração unilateral e romântica da loucura como libertação das amarras disciplinadoras que presidem à constituição do sujeito moderno. Com efeito, se há um âmbito em que as complexíssimas ambivalências da condição humana - capacidades são incapacidades, insights são formas de cegueira etc. - têm de ser respeitadas in toto, pelo menos tanto quanto possível, é o da experiência esquizo. Vejamos.

Primeiramente, a inserção não problemática da mente em um cenário vivido como evidentemente real, composto de objetos pragmaticamente relevantes e circunstâncias sociossimbólicas de inteligibilidade partilhada, dá lugar a experiências de maior ou menor estranhamento diante do mundo e dos outros, que implica uma conscientizaçáo aguda de um hiato ontológico entre o interior e o exterior. Em vez de uma experiência da própria subjetividade como espontaneamente enlaçada aos cenários mundanos de objetos materiais e símbolos partilhados, o esquizo vivencia seus ambientes como enigmáticos e distantes. Nesses casos, o fechamento da subjetividade sobre si mesma, acompanhado pela ideação de um mundo exterior de númenos ou "coisas em si" que parecem para sempre inacessíveis ao alcance do subjectum, não constitui uma ficção filosófica fabricada por preocupaçóes epistêmicas com a validade do conhecimento, mas uma sensação muito real de um abismo entre a própria subjetividade e o universo exterior. Nessa modalidade de experiência não psicótica (ou pré-psicótica), não se observa no indivíduo afetado (pelo menos, não ainda) quaisquer alteraçóes no conteúdo de suas percepçóes sensoriais ou de suas crenças substantivas sobre o mundo, mas sim uma mudança inefável na "atmosfera mental" que colore sua vida subjetiva, no modo como o indivíduo sente (lato sensu) a realidade (PETERS, 2014a).

Um mundo da vida até entáo experimentado como familiar e autoevidente adquire, portanto, uma aura de estranheza e ininteligibilidade que os indivíduos, muitas vezes, só conseguem expressar a outros através de expressóes difusas como "tudo está diferente" ou "há alguma coisa...não sei o que é, mas há alguma coisa" (JASPERS, 1979a, p. 121). A sensação profunda e difusa de estranhamento substitui o senso "merleau-pontyano" de existir como uma subjetividade encarnada e embebida em uma realidade material partilhada com outros, bem como dinamicamente orientada para nela intervir. O "contato vital com o mundo" - na expressão que é do psiquiatra 
EugèneMinkowski $(1958 ; 2002)$, mas que poderia muito bem ter sido assinada pelo próprio Merleau-Ponty - dá lugar a uma angustiada experiência de distanciamento ontológico entre o interior e o exterior, este último adquirindo mais e mais um caráter de irrealidade: "A realidade se afasta de mim. Tudo o que eu toco..., todo mundo que conheço, torna-se irreal táo logo eu os abordo" (SASS, 1992, p. 353).

Um filósofo pode alimentar, no plano estritamente intelectual, severíssimas dúvidas céticas acerca da confiabilidade de suas impressóes e crenças sobre o real, no mesmo passo em que experimenta difusamente seu corpo e mente como firmemente ancorados em um mundo que ele sabe "visceralmente" existir independentemente dele - ainda que náo possa demonstrar tal existência como uma certeza apodíctica. A maior parte dos casos de esquizofrenia principia precisamente com uma dissolução desse senso de realidade inseparavelmente cognitivo e afetivo, corpóreo e intelectual (SASS, 1992, p. 425; FUCHS, 2005a; BURTON, 2008). Enquanto a filósofa entretém intelectualmente a possibilidade epistêmica de que todos os indivíduos e objetos com os quais ela depara sejam irreais, simples aparências fantasmagóricas produzidas pela sua mente, o paciente esquizofrênico percebe efetivamente uma aura de irrealidade ou artificialidade pairar sobre todas as entidades que encontra. Repare-se que esta experiência pode ocorrer mesmo na ausência de qualquer crença propriamente delirante ou psicótica de que os objetos e pessoas percebidos são simples criaçóes da mente do indivíduo - como veremos em detalhe, teorias delirantes surgem muitas vezes como tentativas de oferecer alguma ordem e sentido ao que é primeiramente apenas uma vivência difusa.

Como em um castelo de cartas, as fissões ou rupturas em uma das conexóes constitutivas da práxis cotidiana podem afetar significativamente as demais. A intensa ansiedade desencadeada pela desconfiança em relaçáo ao mundo ambiente revela o quanto nossa experiência "normal" de segurança ontológica ancora-se no realismo ingênuo segundo o qual "vemos as coisas mesmas" (MERLEAU-PONTY, 1971, p. 15) e "os mundos natural e social são o que parecem ser" (GIDDENS, 2003, p. 444). Uma subjetividade moldada por experiências socializadoras em tal ou qual contexto social é capaz de interiorizar gradualmente suas injunçóes objetivas sob a forma de disposiçóes mentais e corporais infraconscientesajustadas às condiçóes estruturais em que o indivíduo se encontra. Como Bourdieu não se cansou de sublinhar, este 
ajuste prático propiciado pela habituação implica uma naturalização tácita das nossas circunstâncias sociais de ação e experiência, espontaneamente vividas não como acordos sócio-históricos contingentes, mas como facticidades objetivas inscritas na própria ordem das coisas. A partir do momento em que o indivíduo é, por assim dizer, assaltado por um ceticismo vivido que não mais suspende dúvidas quanto às fundaçóes da realidade (a suspensão a que Schutz chamou de "epoché da atitude natural" [1967, p. 229]), sua percepção do mundo passa por um processo de "desnaturalização" que, embora não deixe de ser sociologicamente sagaz à sua maneira, gera marcada confusão e perplexidade.

Uma vez que a confiança na facticidade dos modos socialmente padronizados de conduta e interação é uma das condiçóes para o funcionamento fluente dos hábitos mentais e corpóreos, as práticas do sujeito já não se ajustam às exigências de seus contextos segundo aquela espontaneidade inconsciente própria da açáo "normal". O desajuste percebido por si próprio e por outros acaba reforçando um sentimento interno de alienaçáo, enquanto o estranhamento das formas de agir, pensar e sentir que outros tomam por evidentes estimula o indivíduo a problematizar, de modo explícito e reflexivo, o que as pessoas "normais" podem abandonar às operaçóes infraconscientes do hábito. Isto significa que os esquizos têm de superutilizar os recursos escassos de sua consciência reflexiva para realizar procedimentos intelectuais e corporais que outros deixariam a cargo de disposiçóes inconscientes. Por exemplo, um sujeito com plena confiança na sua "héxis corporal" (BOURDIEU, 1999) pode concentrar-se explicitamente no assunto de uma conversa, enquanto um indivíduo incerto quanto aos modos socialmente apropriados de conduzir a própria corporeidade terá sua atenção dividida. Além disso, a tentativa de realizar, por um controle reflexivo, performances normalmente conduzidas pelo hábito pode imprimir no estilo do esquizo uma marca de artificialidade ou afetação - formas de "impropriedade situacional" (GOFFMAN, 1963, p. 216) - que dificulta sobremaneira seus relacionamentos.

Como mostrado pelo influxo "culturalista” (RECKWITZ, 2002) nas teorias sociais praxiológicas, a naturalidade e autoevidência com que um cenário social pode ser experimentado pelo indivíduo deriva, em parte, do fato de que as ações desempenhadas ali são tornadas inteligíveis pelo recurso a esquemas simbólicos de interpretaçáo bem assentados, a ponto de funcionarem como 
diretrizes espontâneas da mente em suas atribuiçóes ordinárias de sentido ao mundo. $\mathrm{O}$ estranhamento esquizo introduz uma perturbação também na operaçáo de tais estruturas subjetivas de percepçáo e classificaçáo dos eventos mundanos. Uma vez que estes deixam de ser rápida e náo problematicamente tipificados pelos sujeitos em suas caminhadas pelo universo social, as tarefas impostas à sua cognição aumentam significativamente. Se os esquemas socioculturalmente partilhados de tipificação de situaçóes reduzem a complexidade cognitiva da orientaçáo do agente pelo mundo, enquadrando uma miríade potencialmente desconcertante de objetos em um punhado manejável de categorias, o enfraquecimento ou dissoluçáo daqueles esquemas na mente do indivíduo como que o lança de volta a um mundo experiencial muito mais confuso e multifacetado.

As ferramentas simbólicas de categorização das situaçôes sociais em que os indivíduos circulam, ao tornarem tais situaçóes inteligíveis, imbuem o indivíduo com orientaçóes capacitadoras acerca dos modos normativamente apropriados de conduta possíveis naquela situação, bem como com um "horizonte de expectativas" a respeito do que é provável ou improvável em tal ou qual contexto. Em contrapartida, o maior ou menor desligamento do esquizo quanto àquelas ferramentas pode levá-lo não apenas a portar-se de formas socialmente desaprovadas, como também a adentrar cenários de experiência com um horizonte muito mais largo de expectativas quanto a desenlaces possíveis. Embora isto possa indubitavelmente incentivar interpretaçóes e atitudes criativas, também pode muito bem engendrar uma experiência de "insegurança ontológica" (LAING, 1990, p. 39) ou "agorafobia metafísica" (BERGER, 1972, p. 75) diante de tantas possibilidades distintas. Ao mesmo tempo, a independência deliberada ou involuntária quanto às "formas de classificaçáo" (DURKHEIM e MAUSS, 2000) sociossimbólica vigentes no seu meio pode dar ensejo a maneiras peculiaríssimas de associar cognitivamente eventos e objetos. Em alguns casos, tais peculiaridades nos procedimentos cognitivos e usos da linguagem entre os esquizos podem ser facilmente inteligidas como desvios identificáveis do "conformismo cognitivo" (DURKHEIM, 1996, p. 24) próprio à normalidade - por exemplo, como exacerbaçáo dos aspectos concretos dos objetos em detrimento dos seus caracteres abstratos e tipificáveis ou o inverso. Em outros, como acontece na classificaçáo dos animais naquela enciclopédia chinesa de Borges que tanto agradou Foucault (2002), a única propriedade discernível no modus cognoscendi do esquizofrênico, ao 
menos desde um ponto de vista exterior, é o seu caráter desviante, idiossincrático ou bizarro em relação aos hábitos cognitivos existentes no seu meio.

No mesmo passo em que recuperam a centralidade das faculdades cognitivas para a explicação da conduta social, as abordagens praxiológicas conferem destaque ao entrelaçamento da cognição com os propósitos práticos que impulsionam nossas intervenções sobre o mundo societário. Se nossos procedimentos cognitivos operam, sobretudo, segundo uma lógica do conhecer para agir, uma perturbação em uma dessas dimensóes tende a afetar significativamente o feitio da outra. Enquanto alguns psiquiatras conferiram tremenda importância às desordens de pensamento e linguagem na condição esquizofrênica, outros enfatizaram o quanto tal condição incidia sobre a esfera volitiva ou conativa da personalidade, dissolvendo as motivaçóes que impulsionariam o indivíduo a intervir no mundo e levando, assim, a uma profunda apatia. Tal conjuntura mostra que uma leitura da condição esquizo a partir da praxiologia, e vice-versa, deve articular a tradicional teoria da ação a uma teoria da inação e de suas causas e efeitos.

As rupturas esquizoides ou esquizofrênicas dos elementos que alicerçam uma experiência ontologicamente segura de inserção vital na realidade podem penetrar ainda mais fundo, dissolvendo a própria vivência do meu corpo como meu ou das minhas experiências subjetivas como minhas (a contradição da linguagem descreve, é claro, uma vivência intrinsecamente contraditória). Em vez da autoidentidade tacitamente suposta como pano de fundo inquestionável dos eventos ocorridos na mente, surgem experiências peculiares de "alienação introspectiva" (GRAHAM; STEPHENS, 1994, p. 92) em que o sujeito mantém a consciência quanto à natureza subjetiva de tal ou qual evento (isto é, sua presença no seu campo de atenção), mas não mais consegue identificá-lo como seu. Nos cenários de psicose, a perda do senso vivido de controle intencional sobre a própria subjetividade se manifesta, por exemplo, em sintomas de "inserção de pensamento", nos quais o indivíduo literalmente crê que os pensamentos de outra entidade invadem sua mente:

Eu olho pela janela, e penso que o jardim parece bonito e a grama parece bacana, mas os pensamentos de Eamonn Andrews (um famoso apresentador de rádio e TV no Reino Unido) vêm à minha mente...[...] Ele trata minha mente como uma tela, e projeta seus pensamentos nela. (apud SASS, 1999, p. 26I). 
Louis Sass e Joseph Parnas (2001, p. 109) relatam outro contundente caso de perturbação da autoidentidade que se encaixa no que Laing denominou o temor da própria aniquilação através do "engolfamento" (LAING, 1990, p. 43) de si pelo outro. Um jovem sentia-se frequentemente confuso ao participar de conversas devido à dificuldade em distinguir entre si mesmo e o seu interlocutor. Ao ver-se, no curso da conversa, sem saber quais pensamentos/ enunciados teriam advindo dele e quais seriam provenientes do seu parceiro de fala, ele experimentava uma atemorizante sensação de ter tido sua mente invadida pelo outro - de modo tal que sua existência mesma estava em risco. Embora a fobia do engolfamento possa levar o indivíduo a buscar isolar-se de outros, tal estratégia náo neutraliza necessariamente a experiência de si como ontologicamente precária e ameaçada. Com efeito, o mesmo sujeito citado, ao caminhar pela rua, evitava cuidadosamente a contemplação do seu reflexo em espelhos ou outras superfícies de vidro, pois isto gerava nele uma angustiada incerteza quanto a qual dos lados ele efetivamente estava.

Pode haver também uma dissociação sentida entre si e o corpo, em que o senso de encarnação da subjetividade é substituído por um estranhamento quanto à própria fisicalidade. A radicalização dessa vivência de autoestranhamento corpóreo pode redundar, ainda, na perda do senso de coerência ou integraçáo entre as diferentes partes do aparato corporal, que passam a ser sentidas como se estivessem desconectadas umas das outras. Por vezes, a intensidade da experiência é tamanha que resulta em um pânico diante da iminência sentida da desintegração ou "despedaçamento" literal do próprio corpo. Em outros casos, os indivíduos são acometidos pela sensação de que passaram por significativas transformaçóes morfológicas, tais como alteraçóes no tamanho ou no peso do seu corpo inteiro ou de algumas de suas partes, com o sentimento desembocando, por vezes, em ilusóes de ótica que confirmam essas impressóes. A autoestranheza pode ainda ser favorecida pelo encontro com espelhos, com alguns evitando a visão do próprio reflexo como ameaçadora, enquanto outros a examinam intensamente enquanto a experimentam como deformada ou morta (SASS; PARNAS, 2002, p. 107).

O exame de si diante do espelho serve, por fim, como metáfora para o círculo infernal de metarreflexividade infinita que pode acometer o esquizo, o qual mobiliza o escrutínio autorreflexivo na tentativa de compreender suas experiências de estranhamento de si próprio, do mundo material e/ou das outras 
pessoas apenas para descobrir a força de radicalização da estranheza na capacidade humana de objetivar a si mesmo, bem como de objetivar a objetivação, assim como a objetivação da objetivação da objetivação da objetivaçáo...em uma vertigem existencial autorreferente que poderíamos descrever como o equivalente psicológico da multiplicação de reflexos que ocorre quando colocamos um espelho diante do outro.

Como vimos, a caracterização heurística da experiência esquizo como o reverso da praxiologia, reverso que significa também um conjunto de "atitudes filosóficas" existencialmente vividas, carrega um respeito a uma condição tão radicalmente ambivalente que nos força a trilhar uma via média entre as celebraçóes românticas da loucura como libertação frente aos processos de disciplinamento da subjetividade, de um lado, e as reduçóes psiquiátricas simplórias de todas as formas de esquizofrenia a meros déficits de funcionamento cognitivo, afetivo e prático, de outro. Por um lado, não há dúvida de que existe um sentido em que a alienação do esquizo em relação aos padróes de cognição, fala e ação operantes no seu milieu está imbuída de sagacidade filosófica. Ela pode exibir, por exemplo, uma consciência argutamente "sociológica" da naturalizaçáo fictícia por trás de rituais sociais e institucionais ou da dose de aposta epistemologicamente "leviana" na correção cognitiva de nossas crenças e impressóes ordinárias sobre o mundo ${ }^{8}$.

Ao mesmo tempo, tal sagacidade cobra seus preços sob a forma de severos desajustes funcionais e sofrimentos psíquicos: por exemplo, a ampliação da consciência reflexiva de múltiplas possibilidades confunde mais do que esclarece, obstando intervençóes decisivas e vigorosas sobre o curso dos eventos,

8 "Os filósofos têm nos mostrado que, cognitivamente, existem poucos, se é que existe algum, aspectos de nossa existência pessoal dos quais podemos estar certos. [...] Certas questões - 'Eu realmente existo?' 'Eu sou hoje a mesma pessoa que era ontem?' 'As outras pessoas realmente existem?' 'Isto que vejo diante de mim continuará a existir quando eu virar as costas?' - não podem ser respondidas de forma indubitável por qualquer argumento racional. [...] Imagine alguém que se aflige profunda e constantemente, pensando se os outros nutrem intenções maliciosas contra si. Ou imagine uma pessoa que se preocupa constantemente com a possibilidade de uma guerra nuclear e não pode deixar de lado o pensamento deste risco. Embora individuos 'normais' possam considerar estas ansiedades, quando são profundas e crônicas, como irracionais, estes sentimentos são mais o resultado de supersensibilidade emocional do que de irracionalidade. Pois o risco de guerra nuclear está sempre aí como uma possibilidade imanente do mundo atual; e, como nenhum indivíduo jamais tem acesso direto aos pensamentos de um outro, ninguém pode estar absolutamente seguro, num sentido mais lógico do que emocional, de que ideias maliciosas não estejam constantemente na mente de outros com quem se interage" (GIDDENS, 200 Ia, p. 95-96). 
enquanto uma implacável atenção "protosaussuriana” ao caráter puramente convencional ou "arbitrário" dos vínculos entre significante e significado confere ao discurso de certos esquizos uma qualidade singularmente "desorganizada" (para utilizar o termo diagnóstico mais frequente). Poder-se-ia ainda dar vários outros exemplos de reversos esquizoides e esquizofrênicos da experiência cotidiana tal como retratada na teoria social praxiológica, no que toca, por exemplo, ao manejo de abstraçóes e concretudes na cogniçáo ordinária, aos requisitos "teatrais" ou "dramatúrgicos" da ação social ou aos aspectos "ativo" e "passivo" da vida subjetiva (para discussóes mais detalhadas, ver PETERS, no prelo).

\section{Conclusão}

A exploração da interface entre psicopatologia e teoria da ação aqui aventada tem uma espécie de precedente ilustre nos vínculos intelectuais entre a sociologia compreensiva de Max Weber e a metodologia "pluralista" do autor de um dos principais manuais na psiquiatria do século XX: Karl Jaspers?. Tal como Weber trilhou uma via média entre as versóes mais radicais do monismo naturalista e do dualismo interpretativista na sociologia, o alentado tratado de Jaspers sobre Psicopatologia geral (1979a; 1979b) também esposava um pluralismo metodológico que se propunha a explorar os recursos das Geisteswissenschaften na descrição atenta e minuciosa da experiência psicopatológica, sem se fechar, no entanto, às possibilidades de explicação causal da doença mental por uma via neurofisiológica, como rezava o método da predileção de Kraepelin e seus discípulos.

Não obstante sua vigorosa defesa da inescapabilidade da interpretação de significados e de descriçóes da experiência vivida na psiquiatria, graças às quais esta se incluiria no território das humanidades tanto quanto naquele da ciência biológica, Karl Jaspers julgou serem as vivências especificamente esquizofrênicas tão singulares que terminou desembocando em uma espécie de niilismo hermenêutico ante essa condição, situando-a, pelo menos em larga medida, para além do que seria "empatizável" a um olhar externo:

9 Para a apreciação filosófica pessoal do trabalho de Weber por Jaspers, ver Jaspers (1977). 
A diferença mais profunda que existe na vida psíquica parece ser aquela a notar entre a vida para nós empática, compreensível, e a vida incompreensível, por sua maneira, isto é, a vida desvairada, louca, no sentido autêntico: a vida esquizofrênica (sem que haja, necessariamente, ideias delirantes). A vida psíquica patológica do primeiro tipo podemos apreender, intuitivamente, como aumento ou diminuição de fenômenos que conhecemos e como ocorrência de tais fenômenos sem os fundamentos e motivos normais. Mas só insuficientemente é que apreendemos, desta maneira, a vida psíquica do segundo tipo. Dão-se, aí, a bem dizer, alterações das mais gerais, que não podemos vivenciar intuitivamente, mas que buscamos, por algum modo, fazer compreensíveis de fora. As doenças afetivas parecem-nos empatizáveis e naturais; as loucuras, absolutamente inempatizáveis e inaturais. Porque a teoria até o momento mais acertada faz os traços particulares desta vida psíquica incompreensível derivarem de cisões ou dissociações da vida psíquica, Bleuler deu-lhe o nome de esquizofrenia... [...] Se considerarmos os elementos fenomenológicos, encontraremos na vida psíquica mórbida aqueles que vemos com dificuldade, sim, mas afinal claramente, em condições favoráveis; e aqueles que nunca podemos ver, em princípio, que só podemos descrever de forma negativa, isto é, pelo que não são. (JASPERS, 1979b, p. 700-70I).

O domínio intuitivamente empatizável do que Jaspers denomina "doenças afetivas" se deixaria compreender, por indivíduos normais, como um âmbito de exacerbaçóes ou intensificaçôes de estados psíquicos comuns entre os seres humanos: a depressão como uma forma magnificada de tristeza, o pânico como o medo levado ao paroxismo, a mania como inflaçáo insensata dos sentimentos de euforia e autoconfiança, e assim por diante. A acessibilidade intuitiva de tais experiências psicopatológicas contrastaria fortemente, segundo o autor alemáo, com quadros de esquizofrenia em que os próprios alicerces fundamentais que ancoram tacitamente a experiência humana do mundo são radicalmente alterados, como os referenciais de tempo, espaço, autoidentidade, coerência lógica e semântica, em suma, os parâmetros existenciais mesmos que organizam nossa vivência da realidade e dão a ela algum senso de estabilidade. Nesses casos, os eventos percebidos no mundo externo podem adquirir, como vimos, um inquietante e inefável sentido de irrealidade, paralisação, artificialidade ou estranheza. A sensação de alienação e estranheza radical diante do mundo pode prolongar-se ainda para o domínio mais íntimo da autoidentidade, perturbando severamente as orientaçóes subjetivas básicas, normalmente tidas como autoevidentes, que estruturam a experiência "normal", tais como a distinção em relação a outras mentes, a unidade das diferentes partes do self, a continuidade de si ao longo do tempo ou o controle volitivo próprio sobre os rumos do pensamento e das iniciativas práticas. 
Há uma dose de sensatez epistêmica e sensibilidade humanitária na postura de Jaspers diante da extraordinária dificuldade de compreensão empática de experiências táo anômalas do mundo e de si próprio como aquelas que aparecem na esquizofrenia. A aproximação apressada entre experiências humanas normais e patológicas pode incorrer no grave erro intelectual de sacrificar o quão efetivamente singulares são as últimas como modos de ser-no-mundo, sem contar o pecado moral de trivializar os sofrimentos, por vezes atrozes, que as psicopatologias acarretam para os indivíduos por elas afligidos. Não obstante, se, por um lado, reconhecer os próprios limites na tentativa de acessar a peculiaríssima experiência esquizofrênica revela uma justificável autoconsciência epistemológica, a simples desistência do esforço interpretativo em face desses limites, por outro lado, expulsa o indivíduo esquizofrênico do domínio do que é humanamente compreensível, muitas vezes a despeito dos seus esforços desesperados em comunicar suas experiências (dos quais alguns dos documentos mais impressionantes permanecem sendo os escritos mais autobiográficos de AntoninArtaud [1976; 2011]).

Poder-se-ia traçar aqui um paralelo com os dilemas éticos e metodológicos com que depararam investigadores do "testemunho da tragédia". Refletindo longamente acerca de qual atitude seria intelectual e moralmente mais responsável diante de testemunhos das mais horrendas catástrofes humanitárias, autores como Agamben (2008) e Kurasawa (2009, p. 100) julgaram crucial abraçar, sem dissolvê-lo, o paradoxo interno a uma postura hermenêutica que, por um lado, reconhece que não pode alcançar completamente um senso experiencial do que as vítimas realmente sofrem ou sofreram, mas sustenta, por outro lado, que esforços de máxima compreensão empática e reconstrução discursiva das suas experiências têm de ser reiteradamente feitos, apesar - mas também por causa - dessa limitaçáo mesma. Mutatis mutandis, e embora tal aproximaçáo devesse ser realizada com muito mais delicadeza do que estamos em condições de oferecer aqui, poder-se-ia aplicar essa mesma atitude hermenêutica conscientemente ambígua à interpretação do mundo interior do esquizofrênico ${ }^{10}$.

10 A condição esquizo é, na sua constituição mais íntima, eivada de paradoxos e ambivalências. Entre as consequências que se impõem a partir desse modo de vê-la está o cultivo de uma sensibilidade atenta às complexas combinações entre capacidades e incapacidades que a condição acarreta (pelo menos em alguns de seus casos), para além de qualquer redução unilateral seja à sua celebração romântica como uma forma de lucidez 
que transcende a "normose", seja à sua caracterização psiquiátrica como mero déficit. As extraordinárias ambivalências da condição esquizo aparecem também, como era de se esperar, no debate sobre as consequências sociopsíquicas do uso de rótulos psiquiátricos na classificação de suas experiências e comportamentos anômalos. A posição encampada por este trabalho reconhece, por um lado, a necessidade de dar conta das realidades psicológicas que tais designações diagnósticas pretendem, bem ou mal, caracterizar. Pode-se reconhecer a existência dessas realidades sem negar, por outro lado, que categorias psicopatológicas possuem um caráter performativo, isto é, não são apenas instrumentos de designação do comportamento, mas influências causais sobre sua produção, reprodução e transformação. Uma visão dessa natureza pretende escapar tanto à falta de sensibilidade sociológica aos efeitos sociopsíquicos do discurso psiquiátrico, de um lado, quanto à posição (des)construtivista segundo a qual os conceitos psiquiátricos não designam quaisquer realidades para além daquelas que eles próprios constituem performativamente, de outro (SASS, 1999, p. 265). No que toca às suas consequências ético-políticas, por sua vez, essa via média entre "realismo psicológico" e "construtivismo sócio-histórico" acarreta uma atenção intensa tanto aos cenários em que a psiquiatria funciona como uma instituição opressiva quanto àqueles em que ela presta um valioso auxílio a pessoas em situações de extremo sofrimento, cujos problemas não desapareceriam se parássemos de utilizar conceitos psiquiátricos para descrevê-los (MERQUIOR, 1985, p. 30). Seja como for, mesmo quando o rótulo psiquiátrico é aceito, surgem marcadas controvérsias analíticas e terapêuticas a respeito dos modos psicologicamente mais fidedignos $e$ terapeuticamente mais eficazes de utilizá-lo - ab initio, aliás, nada nos garante de antemão que estas duas preocupações (realismo psicológico e utilidade terapêutica) sejam perfeitamente conciliáveis. Um exemplo marcante do problema patenteia-se no debate acerca das implicações científicas e práticas dos termos distintos "pessoa esquizofrênica" e "pessoa com esquizofrenia" (AMERICAN PSYCHIATRIC ASSOCIATION, 2000, p. 31 ; SASS, 2007). A preferência pela segunda expressão responde a uma tentativa compreensivel de barrar a identificação do indivíduo inteiro com a sua psicopatologia. Segundo essa rationale, termos como "esquizofrênico" ou "alcóolatra", por exemplo, encorajariam não apenas a tendência estigmatizante a enxergar a doença mental como coextensiva à pessoa total, mas também a propensão a trivializar a dimensão genuinamente patológica das dificuldades existenciais de certos indivíduos. Ao falar da pessoa com esquizofrenia, em vez da pessoa esquizofrênica, sugerir-se-ia que a doença mental é, antes de tudo, uma entidade que ataca o indivíduo, não uma expressão de sua personalidade ou essência. Nos termos da clássica distinção canguilhemiana entre as concepções egípcia e grega da doença, defensores do rótulo "pessoa com esquizofrenia" se aproximariam da primeira, ao conceberem a patologia como uma entidade distinta e, em princípio, externa ao individuo, entidade que "entra e sai do homem como por uma porta" (CANGUILHEM, 2009, p. 12). Tal visão é também denominada "ontológica" pelo autor francês, na medida em que se associa à ideia de que há uma distinção qualitativa entre os estados normal e patológico. No caso especifico da esquizofrenia, essa distinção qualitativa serviria de antídoto a qualquer aproximação apressada entre os problemas cognitivos, emocionais e práticos enfrentados pelas pessoas com esse transtorno e aqueles enfrentados pelas pessoas normais, aproximação que reduziria as maiores dificuldades e sofrimentos vivenciados pelos primeiros a uma falta condenável de esforço e responsabilidade. Talvez a ilustração clássica desse tipo de insensibilidade apareça nos casos de depressão severa em que um indivíduo vive a ação mais rotineira (e.g., levantar da cama e escovar os dentes) como um esforço hercúleo (JAMISON, 1993), enquanto aqueles ao seu redor o veem apenas como "preguiçoso" ou "irresponsável". Em contraponto à noção ontológica/egípcia da doença, Canguilhem menciona a acepção grega ou "positivista" segundo a qual a patologia não se identifica tanto à invasão do organismo por uma entidade exterior, mas a um desequilibrio e desarmonia no funcionamento do ser humano como um todo. Se a harmonia e o equilibrio das diferentes funções do individuo são propriedades que emergem da sua configuração inteira, "a doença não está em alguma parte do homem. Está em todo homem e é toda dele" (CANGUILHEM, 2009, p. 12). Nesse sentido, em vez de uma cisão qualitativa entre o normal e o patológico, a relação entre os dois estados seria concebida à maneira de um continuum. Diferentes patologias, é desnecessário dizer, se encaixam melhor em uma ou outra de tais concepções: enquanto "doenças infecciosas ou parasitárias", por exemplo, evidenciam a existência de uma invasão pelo patológico, "perturbações endócrinas" 
se encaixam no modelo de uma desarmonia interna (idem). Faz parte da própria natureza de alguns casos esquizofrênicos que eles se identifiquem simultaneamente, em alguma medida, a ambos os modelos de patologia. Por um lado, não há dúvida de que as transformações significativas na relação experiencial com o mundo são frequentemente vivenciadas como alterações não escolhidas. Por outro lado, na medida em que os seres humanos interagem consigo próprios e respondem ativamente às suas experiências de diferentes maneiras, casos concretos de esquizofrenia tornam-se configurações complexas de aflições e atos inter-relacionados. Em alguns cenários, por exemplo, a irrupção da doença propriamente dita representa a culminação ou radicalização de características de personalidade que, em doses menores, já marcavam um modo peculiar de ser-no-mundo, tais como um sentimento de alienação afetiva em relação à realidade circundante e a si próprio. Se a noção de "pessoa com esquizofrenia" captura bem a dimensão da doença como uma espécie de assalto à subjetividade do indivíduo, ela parece deixar de lado o fato de que, em vários aspectos, o rótulo designa também aspectos de um modo relativamente intencional e inteligivel de ser-no-mundo. Não há dúvida de que a ideia de "pessoa esquizofrênica" pode ser apropriada de modo essencialista, bem como instrumentalizada para lançar sobre os ombros dos pacientes a responsabilidade inteira pela sua condição, encorajando modalidades mais hostis e menos compassivas de tratamento. Por outro lado, ao manter o compromisso com a ideia de qualidades especificamente esquizofrênicas de uma pessoa, essa mesma expressão pode encorajar uma percepção de individuos com esquizofrenia como agentes intencionais pertencentes a uma comunidade de entendimento e fala, agentes cujos ditos e feitos merecem ser abordados, pelo menos em princípio, como manifestações potencialmente compreensiveis. Em contraste, ainda que tenha surgido com a intenção louvável de combater a estigmatização ao distinguir a pessoa da sua doença, o modelo biomédico da doença como entidade exterior pode levar, na prática, a interpretações fáceis e apressadas do conjunto do comportamento do paciente como manifestações de sua patologia. Se a pessoa é nitidamente distinta da doença, pode-se abusar do expediente de atribuir seus enunciados e práticas, sem maiores esforços dialógicos e compassivos, ao sujeito "doença". Nenhuma das expressões, nesse sentido, está isenta de problemas. Enquanto o epíteto "esquizofrênico", ao se aproximar de uma concepção do sujeito como um agente intencional e responsável por si, pode levar-nos a negligenciar a sua dependência em relação a redes sociais e institucionais de apoio e tratamento, a ideia de "individuo com esquizofrenia" pode vir a reconhecer tal dependência ao prę̧o de sacrificar suas pretensões à autonomia. Em vez de um trabalho empático de escuta atenta, o sujeito é condescendentemente tratado como uma não pessoa ou uma espécie de criança. Fatores motivacionais potencialmente inteligiveis de sua conduta podem ser ignorados em favor de simples concepções de deficiência, como nos casos de testes de aptidão cognitiva em que o "mau" desempenho de alguns pacientes é atribuido a um déficit intelectual, quando o que está em jogo é algo distinto, como uma perspectiva idiossincrática sobre a significação da prova ou uma recusa intencional a se submeter a ela. Utilizando-se de maneira a-histórica os termos celebrizados por Michel Foucault (1978, p. 540; 559), poder-se ia dizer que, naqueles casos, o "diálogo...entre a razão e a loucura" como uma oportunidade de compreensão de modos peculiares de pensar e sentir o mundo é substituído por um "monólogo... sobre a loucura". Portanto, embora o propósito ético-terapêutico por trás da preferência pela expressão "pessoa com esquizofrenia" pressuponha um foco sobre a dignidade da pessoa, a noção da doença como uma entidade à parte pode muito bem encorajar uma concentração sobre o rótulo diagnóstico em detrimento do respeito à sua personhood. Após essa longa digressão sobre as vantagens $e$ desvantagens de ambas as expressões, cumpre ressaltar que utilizamos os termos intercambiavelmente, embora submetendo ambos a uma vigilância crítica calcada nas considerações que acabamos de fazer. Fulcral dentre estas considerações é a concepção das condições e trajetórias experienciais esquizofrênicas como complexas inter-relações entre aflições que afetam o indivíduo, de um lado, $e$ atos intencionais que expressam sua personalidade, de outro. Por mais conceitualmente desconfortável que seja esta concepção, ela pretende escapar às tentações analíticas antípodas de supor seja que a pessoa e a sua psicopatologia são completamente idênticas, seja, ao contrário, que elas são completamente distintas e separáveis. Uma visão como esta recusa, nesse sentido, tanto a perspectiva segundo a qual "o papel da pessoa no distúrbio mental...é periférico, meramente o de uma vítima passiva de uma doença a ser consertada pela medicina", quanto "a visão de que 
É nesse sentido que várias das condiçôes de espírito e formas de experiência esquizoides e esquizofrênicas não podem ser lidas como simples déficits, mas como possibilidades alternativas do ser-no-mundo humano. Assim como acontece com achados históricos e etnológicos, a descrição minuciosa dessas experiências não apenas amplia nossorepertório de conhecimentos sobre a humanitude da humanidade, isto é, sobre o que torna humanos os humanos, mas também joga uma nova luz sobre vários aspectos de nossa existência "nativa" e "normal". No fim das contas, as mais peculiares vivências esquizoides ou esquizofrênicas mostram versóes exacerbadas de desafios e dilemas inerentes à lida do anthropos. O esquizo é o humano assoberbado pela radicalidade com que vive a sua condição, que é também a nossa.

\section{Referências}

AGAMBEN, G. O que resta de Auschwitz: o arquivo e o testemunho. São Paulo: Boitempo, 2008.

AGOSTINHO. Confissóes. São Paulo: Nova Cultural, 2000.

ALEXANDER, J. O novo movimento teórico. Revista brasileira de ciências sociais, n. 2, 1987.

AMERICAN PSYCHIATRIC ASSOCIATION. Diagnostic and statistical manual of mental disorder. 4th edition. Washington, DC, 2000.

ANESHENSEL, C. Mental illness as a career: sociological perspectives. In: ANESHENSEL, C.; PHELAN, J. Handbook of the sociology of mental health. Kluwer Academic/Plenum Publishers, 1999.

ANESHENSEL, C.; PHELAN, J. Handbook of the sociology of mental health. Kluwer Academic/Plenum Publishers, 1999.

ARCHER, M. Structure, agency and the internal conversation. Cambridge: Cambridge University Press, 2003.

a pessoa e a sua doença são idênticas" (STRAUSS, 1989, p. 182). Tendo isto em mente, quando mencionamos o esquizo, esquizoide ou esquizofrênico, para economizar tinta em um trabalho que já se prestou mais do que o suficiente a efusões prolixas, naturalmente não esteve implícita qualquer sugestão de que um esquizofrênico não seja nada além desse atributo - do mesmo modo como podemos dizer que dois indivíduos são, digamos, brasileiros (pessoas com cidadania brasileira) e médicos (pessoas que exercem a medicina) sem supor que quaisquer dos atributos esgotem a sua personalidade ou eclipsem diferenças importantes entre eles. 
ARTAUD, A. Selected writings. SONTAG, S. (Ed.). Berkeley/Los Angeles: University of California Press, 1976.

Linguagem e vida. São Paulo: Perspectiva, 2011.

BECKER, H. Outsiders: studies in the sociology of deviance. New York: Free Press, 1963.

BENEDICT, R. Anthropology and the abnormal.Disponível (versão reduzida) em: http:// dsc.dixie.edu/owl/syllabi/English2010/BenedictEthical\%20Relativism.pdf. Acesso em: 31/12/2009.

Patternsofculture. London: Routledge, 1961.

BERGER, P. Perspectivas sociológicas. Petrópolis: Vozes, 1972.

O dossel sagrado: elementos para uma teoria sociológica da religiáo. São Paulo: Paulu, 2003.

BERGER, P.; LUCKMANN, T. A construção social da realidade. Petrópolis: Vozes, 1985.

BINSWANGER, L. Três formas da existência malograda: extravagância, excentricidade e amaneiramento.Rio de Janeiro: Zahar, 1977.

BLANKENBURG, W. First steps toward a psychopathology of 'common sense'. Philosophy, psychiatry \& psychology, v.8, n.4, p. 303-315, 2001.

BLEULER, E. Dementia praecox or the group of schizophrenias. New York, International Universities Press, 1969.

BOURDIEU, P. Sociologia. Coleção Grandes Cientistas Sociais. Renato Ortiz (Org.). São Paulo, Ática, 1983.

Liçốes da aula. São Paulo: Ática, 1988a.

Coisas ditas. São Paulo: Brasiliense, 1990a.

The logic of practice. Stanford: Stanford University Press, $1990 \mathrm{~b}$.

A dominação masculina. Rio de Janeiro: Bertrand Brasil, 1999.

BOURDIEU, P.; WACQUANT, L. An invitation to reflexive sociology. Chicago: University of Chicago Press, 1992.

BURTON, R. Being certain: believing you're right even when you're not.New York: SaintMartin's Press, 2008.

CANGUILHEM, G. O normal e o patológico. Rio de Janeiro: Forense Universitária, 2006. 
COCKBURN, P.; COCKBURN, H. Os demônios de Henry. Rio de Janeiro: Jorge Zahar, 2011.

CORCUFF, P. As novas sociologias. Bauru: Edusc, 2001.

CROSSLEY, N.The phenomenological habitus and its construction. Theory and society, v. 30, p. 81-120, 2001a.

The social body: habit, identity and desire. Sage: London, $2001 \mathrm{~b}$.

DREYFUS, H. Being-in-the-world: a commentary on Heidegger's Being and Time, Division 1.Cambridge: MIT Press, 1991.

DURKHEIM, E. As formas elementares da vida religiosa. São Paulo: Martins Fontes, 1996.

.; MAUSS, M. Algumas formas primitivas de classificação. In: RODRIGUES, J.A. Durkheim: sociologia. São Paulo: Ática, 2000.

ELIAS, N. A sociedade dos indivíduos. Rio de Janeiro: Jorge Zahar, $1994 \mathrm{~b}$.

FEENBERG, A. Questioning technology. London: Routledge, 1999.

FOUCAULT, M. História da loucura. São Paulo: Perspectiva, 1978.

As palavras e as coisas: uma arqueologia das ciências humanas. São Paulo: Martins Fontes, 2002.

FREUD, S. O ego e o id e outros trabalhos (1923-1925). Edição Standard Brasileira das Obras Completas de Sigmund Freud, v. 19. Rio de Janeiro: Imago, 1976 b.

FRITH, C.; JOHSNTONE, E. Schizophrenia: a very short introduction. Oxford, Oxford University Press.

FUCHS, T. The tacit dimension. Philosophy, psychology \& psychiatry, v. 8, n. 4, p. 323-326, 2001.

"Melancholia as desynchronization: towards a psychopathology of interpersonal time". Psychopathology, v. 34, p. 179-186, 2001.

- The challenge of neuroscience: psychiatry and phenomenology today. Psychopathology, v. 35, p. 319-326, 2002.

The phenomenology of shame, guilt and the body in Body Dysmorphic Disorder and Depression. Journal of phenomenological psychology, v. 33, n. 2, p. 223-243, 2003a.

Mind, meaning, and the brain. Philosophy, psychology \& psychiatry, v. 9, n. 3, p. 261-264, 2003b. 
. Delusional mood and delusional perception - a phenomenological analysis. Psychopathology, v. 38, p. 133-139, 2005a.

Corporealized and disembodied minds: a phenomenological view of the body in melancholia and schizophrenia. Philosophy, psychology \& psychiatry, v. 12, n. 2, p. $95-107,2005$ b.

. The temporal structure of intentionality and its disturbance in schizophrenia. Psychopathology, v. 40, p. 229-235, 2007.

Phenomenology and psychopathology. In: Schimicking, D.; Gallagher, S. Handbook of phenomenology and cognitive science. Dordrecht: Springer, 2010.

The psychopathology of hyperreflexivity. Journal of speculative philosophy, v. 24, n. 3, 2011.

FUCHS, T.; SCHLIMME, J. E. Embodiment and psychopatholody: a phenomenological perspective. Current psychiatry, v. 22, p. 570-575, 2009.

; HAAN, S. de. The ghost in the machine: disembodiment in schizophrenia - Two case studies. Psychopathology, v. 43, p. 327-333, 2010.

GADAMER, H. G. Verdade e método. Petrópolis: Vozes, 1997.

GARFINKEL, H. Studies in ethnomethodology. Nova Jersey: Prentice-Hall, 1967.

GEERTZ, C. A interpretação das culturas. Rio de Janeiro: LTC, 1989.

Local knowledge: further essays in interpretive anthropology. New York: Basic Books, 2000.

GIDDENS, A. Central problems in social theory: action, structure and contradiction in social analysis. London: Macmillan, 1979.

Sociologia: uma breve, porém crítica introdução. Rio de Janeiro: Zahar, 1984.

London: Polity Press, 1993.

Política, sociologia e teoria social. São Paulo: Unesp, 1998.

A constituiçáo da sociedade. São Paulo: Martins Fontes, 2003.

GOFFMAN, E. Behavior in public places. New York: Free Press, 1963.

GRAHAM, G.; STEPHENS, L. Philosophical psychopathology. Cambridge, MA/London: MIT Press, 1994.

GRAHAM, G. The disordered mind. London: Routledge, 2010. 
GUSMÃO, L. O fetichismo do conceito: limites do conhecimento teórico na investigação social. Rio de Janeiro: TopBooks, 2012.

HABERMAS, J. O discurso filosófico da modernidade. São Paulo: Martins Fontes, 2000b. HEIDEGGER, M. Ser e tempo.Petrópolis: Vozes, 2006.

HONNETH, A.; JOAS, H. Social action and human nature. Cambridge: Cambridge University Press, 1988.

JAMISON, K. R. Touched with fire: manic-depressive illness and the artistic temperament. New York: Free Press, 1993.

JASPERS, K. Método e visão de mundo em Weber. In: COHN, G. (Org.). Para ler os clássicos. Rio de Janeiro: Livros Técnicos e Científicos, 1977.

Psicopatologia geral: psicologia compreensiva, explicativa e fenomenologia (v. 1). Rio de Janeiro/São Paulo: Atheneu, 1979a.

Psicopatologia geral: psicologia compreensiva, explicativa e fenomenologia (v. 2). Rio de Janeiro/São Paulo: Atheneu, 1979b.

JENKINS, J. H.; BARRET, J. (Orgs.). Schizophrenia, culture and subjectivity: the edge of experience. New York: Cambridge University Press, 2004.

.; __ Introduction. In: JENKINS, J. H.; BARRET, J. (Orgs.). Schizophrenia, culture and subjectivity: the edge of experience. New York: Cambridge University Press, 2004.

JENKINS, J. H. Schizophrenia as a paradigm case for fundamental human processes. In: JENKINS, J. H.; BARRET, J. (Orgs.). Schizophrenia, culture and subjectivity: the edge of experience. New York: Cambridge University Press, 2004.

KURASAWA, F. The ethnological imagination: a cross-cultural critique of modernity. Minneapolis: University of Minnesota Press, 2004.

A message in a bottle: bearing witness as a mode of transnational practice. Theory, cultureandsociety, London, v.26, n.1, p. 92-111, 2009 b.

LAHIRE, B. Esboço do programa científico de uma sociologia psicológica. Educação e pesquisa, v. 34, n. 2, 2008.

LAING, R. The divided self: an existential study in sanity and madness. Harmondsworth: Penguin, 1974.

LATOUR, B. On interobjectivity. Mind, culture, and activity, v. 3, n. 4, p. 228-245, 1996. 
Reassembling the social: an introduction to actor-network theory. Oxford: Oxford University Press, 2005.

MARX, K. O 18 brumário e cartas a Kugelman. Rio de janeiro: Paz e Terra, 1974.

Manifesto do partido comunista \& teses sobre Feuerbach. São Paulo: Martin Claret, 2000.

MEAD, G.H. Mind, self and society: from the standpoint of a social behaviorist. Chicago: Chicago University Press, 1934.

MERLEAU-PONTY, M. O visível e o invisível. São Paulo: Perspectiva, 1971. . Fenomenologia da percepçáo. São Paulo: Martins Fontes, 2002.

MERQUIOR, J.G. O argumento liberal. Rio de Janeiro: Nova Fronteira, 1981.

Foucault. London: Fontana, 1985.

MILLS, C.W. A imaginação sociológica. Rio de Janeiro: Jorge Zahar, 1975.

MINKOWSKI, E. Findings in a case of schizophrenic depression. In: MAY, R. Existence: a new dimension in psychiatry and psychology. New York: Basic Books, 1958.

. The essential disorder underlying schizophrenia and schizophrenic thought. In: CUTTING, J.; SHEPERD, M. The clinical roots of the schizophrenia concept: translations of seminal European contributions on schizophrenia. Cambridge: Cambridge University Press, 1987.

La schizophrénie. Paris: Petite BibliothèquePayot, 2002.

MORGAN, A. Schizophrenia, reification and deadened life. History of the human sciences, v. 23, n. 5, p. 176-193, 2010.

PARKER, J. Structuration. Philadelphia: Open University Press, 2000.

PETERS, G. A praxiologiaculturalista de Anthony Giddens. Teoria \& pesquisa, v. 20, n.1, p. 123-147,2001c.

Agência, estrutura e práxis: uma leitura dialógica da teoria da estruturação. Teoria $\&$ sociedade, v. 19, n. 1, p. 8-39, 2011d.

Habitus, reflexividade e neo-objetivismo na teoria da prática de Pierre Bourdieu.

Revista brasileira de ciências sociais, v. 28, n. 83, p. 47-71, 2013 b.

Explanation, understanding and determinism in Pierre Bourdieu's sociology. History of the human sciences, v. 27, n. 1, p. 124-149, 2013 c. 
. Ordem social e (in)segurança ontológica: esboços de existencialismo sociológico em Anthony Giddens, Peter Berger e Pierre Bourdieu. Política \& trabalho, v. 40, 2014 a.

Percursos na teoria das práticas sociais: Anthony Giddens e Pierre Bourdieu. São Paulo: Annablume, 2015.

A ordem social como problema psíquico: do existencialismo sociológico à epistemologia insana. São Paulo: Annablume, no prelo.

PLATÃO. Apologia de Sócrates. In: Platão (Os pensadores). São Paulo: Nova Cultural, 1996.

PLESSNER, H. Laughing and crying: a study of the limits of human behavior. Evanston: Northwestern University Press, 1970.

RECKWITZ, A. Toward a theory of social practices: a development in culturalist theorizing". European journal of social theory, v. 5, n. 2, p. 243-263, 2002.

SAHLINS, M. Ilhas de história. Rio de Janeiro: Jorge Zahar, 1999.

SARTRE, J. P. A náusea. Rio de Janeiro: Nova Fronteira, 1983.

SASS, L. Madness and modernism: insanity in the light of modern art, literature, and thought. New York: Basic Books, 1992.

Analyzing and deconstructing psychopathology. Theory \& psychology, v. 9, n. 2, p. $257-268,1999$.

- 'Schizophrenic person' or 'Person with schizophrenia'?: an essay on illness and the self. Theory \& psychology, v. 17, n. 3, p. 395-420, 2007.

. Negative symptoms, commonsense, and cultural disembedding in the modern age. In: JENKINS, J. H.; BARRET, J. (Orgs.). Schizophrenia, culture and subjectivity: the edge of experience. New York: Cambridge University Press, 2004.

SASS, L.; NELSON, B. Medusa's stare: a case study of working with self-disturbance in the early phase of schizophrenia. Clinical case studies, v. 8, n. 6, 2009.

SASS, L.; PARNAS,J. Self, solipsism, and schizophrenic delusions. Philosophy, psychiatry, \& psychology, v. 8, n. 2/3, p. 101-120, 2002.

SCHATZKI, T. Social practices: a wittgensteinian approach to human activity and the social. Cambridge: Cambridge University Press, 1996.

SCHEFF, T. Being mentally ill: a sociological theory. Chicago, Aldine, 1966. 
SCHUTZ, A. Collected papers I: the problem of social reality. The Hague: Martinus Nijhoff, 1967. Fenomenologia e relaçóes sociais. Rio de Janeiro: Zahar Editora, 1979.

STRAUSS, J. S. Subjective experiences of schizophrenia: toward a new dynamic psychiatry. Schizophrenia bulletin, v. 15, n. 2, 1989.

SZASZ, T. The myth of mental illness. New York: Hoeber-Harper, 1961.

TAYLOR, C. As fontes do self: a construção da identidade moderna.São Paulo: Loyola, 1997. Merleau-Ponty and the epistemological picture. In: CARMAN, T.; HANSEN, M. The

Cambridge companion to Merleau-Ponty. Cambridge: Cambridge University Press, 2005.

VANDENBERGHE, F. Teoria social realista: um diálogo franco-britânico. Belo Horizonte: UFMG, 2010.

\section{The Theory of Action in the Light of the Schizo Experience: an study of insane epistemology}

\section{Abstract}

The notions of "insane epistemology" and "heuristics of insanity" refer to a methodological device that has proven fruitful in a variety of research domains, namely the plunge into the realm of the "pathological" as a pathway to illuminate "normal" modalities of action and experience. Resorting to this strategy on the plane of sociological characterizations of human conduct, the article harnesses phenomenological and existential descriptions of schizoid and schizophrenic experiences, not only to understand these in the light of the praxeological theory of action, but also to deepen the praxeological theory of action in the light of what such descriptions teach us about the multiplicity of ways of being-in-the-world displayed by the anthropos. The study defends that these transformations, despite their psychic costs, must not be conceived as mere functional deficits, but rather as complex existential attitudes which defy, in practice, certain postulates of the praxeological theory of action: the grounding upon tacit beliefs is replaced with a hyper-reflexive compulsion, the pragmatic relationship with material objects gives way to a quasi-philosophical perplexity in face of their mere reality, the inter-subjective agreements that offer familiarity and order to social reality in a given culture are perceived in their radical ontological arbitrariness, and the estrangement from one's own body ceases to be a playful Cartesian skepticism so as to become a profound existential experience.

Keywords: Action theory. Praxeology. Schizophrenia. Phenomenology. Psychopathology.

Recebido em 20/02/2016

Aceito em 10/11/2016 